\title{
PENGARUH MODEL PEMBELAJARAN LEARNING CYCLE 7E TERHADAP HASIL BELAJAR SISWA PADA MATERI KEANEKARAGAMAN HAYATI KELAS X MIA DI SMA NEGERI 10 PALEMBANG
}

\author{
Mitrayani ${ }^{1}$ \\ Saleh Hidayat ${ }^{2}$ \\ Naintyn Novitasari ${ }^{3}$ \\ ${ }^{\mathbf{1 , 2 3})}$ Pendidikan Biologi FKIP Universitas Muhammadiyah Pale mbang \\ E-mail: mitrayani123@gmail.com,salehhidayat29@gmail.com,naintyn_novitasari@um- \\ pale mbang.ac.id
}

\begin{abstract}
This study aims to: (1) Know the effect of Learning Cycle 7E learning model toward student learning outcomes with the help of powerpoint media and LKS on Xclass biodiversity material MIA in SMA Negeri 10 Palembang, (2) Knowing the difference between the learning outcomes using the model Learning Cycle 7E learning and Conventional learning. The research method used in the form of quasi-experiment (Quasi-experiment), using pretest-posttest group control design. The technique of collecting data by using test and observation sheet. The test is given before and after the treatment, while the observation sheet is given after the treatment. The data obtained were analyzed using paired sample t-test and independent sample t-test. T-test result paired sample t-test, followed by using formula omega and effect size $d$. While the results of t-test independent sample t-test, followed by using the formula effect size $r$. The subject of research is class X MIA at SMA Negeri 10 Palembang, sampling technique used is purposive sampling. The results obtained after using the t-test paired sample t-test, it is known that the significance value of $0.000<0.05$, which means Learning Cycle 7E learning model affects the learning outcomes of students with a percentage of $86 \%$. While the result of t-test independent sample t-test, it is known that the significance value of $0.000<0,05$, which means there is a difference of final result between class which uses Learning Cycle $7 E$ learning model using the conventional method and have percentage equal to $74 \%$.
\end{abstract}

Kata kunci: hasil belajar siswa, Learning Cycle 7E.

Hasil belajar merupakan salah satu bagian terpenting dalam proses pembelajaran, karena hasil belajar merupakan hasil dari suatu interaksi tindak belajar dan tindak mengajar. Jika dilihat dari sisi guru, tindak mengajar (proses pembelajaran) diakhiri dengan proses evaluasi hasil belajar. Sedangkan dari sisi siswa, hasil belajar merupakan berakhirnya pengajaran dari puncak proses belajar.

Berdasarkan hasil wawancara peneliti pada beberapa siswa dan guru biologi di SMA Negeri 10 Palembang pada mata pelajaran
Biologi di bulan April 2017, pada saat proses pembelajaran guru hanya menggunakan metode ceramah, model pembelajaran Number Heads Together (NHT), dan pemberian tugas kepada siswa. Sehingga siswa kurang aktif dalam proses pembelajaran. Kondisi siswa yang kurang aktif dalam pembelajaran berdampak pada hasil belajar siswa yang kurang baik, hal tersebut ditunjukkan dari hasil ujian nasional bahwa nilai pada mata pelajaran biologi tingkat kabupaten Palembang. Nilai di SMA Negeri 10 Palembang yang dilihat pada data 
PAMER UN menunjukkan bahwa $5,88 \%$ siswa yang mendapatkan nilai diatas KKM dan 94,12\% siswa mendapatkan nilai dibawah KKM. Hal ini dapat disimpulkan bahwa ketuntasan belajar secara klasikal yang dicapai masih $5,88 \%$ pada mata pelajaran biologi tahun pelajaran 2016/2017.

Pada mata pelajaran biologi kelas $\mathrm{X}$ juga terdapat materi keanekaragaman hayati. Selain alasan memilih SMA Negeri 10 Palembang, peneliti melihat ruang terbuka hijau sesuai untuk materi keanekaragaman hayati. Berdasarkan pengalaman guru yang mengajar, bahwa siswa sering mengalami kesulitan dalam membedakan antara keanekaragaman hayati pada tingkat gen dengan keanekaragaman hayati pada tingkat spesies. Oleh karena itu, diperlukan suatu model pembelajaran yang dapat mengatasi ketidakmampuan siswa dalam memahami materi pelajaran dan untuk meningkatkan hasil belajar pada siswa. Salah satu model pembelajaran tersebut adalah model pembelajaran Learning Cycle 7E.

Model pembelajaran Learning Cycle 7E dikembangkan dari model pembelajaran Learning Cycle 5E, peran guru pada kedua model tersebut sebenarnya sama yaitu sama-sama berperan sebagai fasilitator dan mediator pembelajaran. Namun terdapat juga perbedaan antara model pembelajaran Learning Cycle 5E dan model pembelajaran Learning Cycle $7 \mathrm{E}$ adalah bahwa pada model pembelajaran pembelajaran Learning Cycle 7E diawali dengan pengungkapan pengetahuan awal siswa tentang suatu topik materi pelajaran melalui pengajuan pertanyaan-pertanyaan oleh guru dan diakhiri dengan pemberian kesempatan kepada siswa untuk mengembangkan dan menerapkan konsep-konsep maupun prinsipprinsip ilmiah yang telah dikuasai pada situasi yang lebih kompleks dalam kehidupan sehari-hari (Sadia, 2014).

Model pembelajaran Learning Cycle 7E merupakansalahsatu model konstruktivis dalam pembelajaran yang digunakan di kelas. Model pembelajaran Learning Cycle 7E berpusat pada siswa (student centere) yang merupakan rangkaian tahaptahap kegiatan yang diorganisasi sedemikian rupa sehingga siswa dapat menguasai kompetensi yang harus dicapai dalam pembelajaran dengan berperan aktif. Model pembelajaran Learning Cycle 7E dikembangkan dari teori perkembangan kognitif Piaget yang berbasis konstruktivisme (Kayati, 2015).

Penelitian ini sudah pernah dilakukan sebelumnya oleh Sutrisno, (2012) mahasiswa FKIP Universitas Sebelas Maret dengan judul penelitian "Implementasi Model Learning Cycle 7E Terhadap Motivasi Belajar Siswa Serta Kaitannya dengan Hasil Belajar Biologi di SMA Negeri 1 Banyudono". Hasil penelitian menunjukkan bahwa ada peningkatan hasil belajar setelah perlakuan dengan menggunakan model Learning Cycle 7E. Namun penelitian ini berbeda dari penelitian sebelumnya, di mana penelitian mengenai model Learning Cycle 7E diterapkan pada mata pelajaran biologi dengan jenis penelitian eksperimen. Persamaan penelitian terdahulu dengan penelitian yang peneliti laksanakan adalah samasama meneliti model Learning Cycle 7E dan hasil belajar, sedangkan perbedaan dengan penelitian terdahulu adalah peneliti bukan meneliti implementasi dan motivasi belajar tetapi meneliti pengaruh model 
Learning Cycle $7 E$ terhadap hasil belajar siswa.

Berdasarkan permasalahan yang telah diuraikan, maka penelitian ini bertujuan untuk: (1) mengetahui pengaruh model pembelajaran Learning Cycle 7E terhadap hasil belajar siswa dengan bantuan media Power Point dan LKS pada materi keanekaragaman hayati kelas X MIA di SMA Negeri 10 Palembang, (2) mengetahui perbedaan antara hasil akhir belajar menggunakan model pembelajaran Learning Cycle 7E dan pembelajaran Konvensional.

\section{METODE}

Penelitian ini dilaksanakan di SMA Negeri 10 Palembang pada kelas $X$ MIA. Penelitian merupakan penelitian eksperimental semu menggunakan desain control grup pretest posttest. Kelas eksperimen (kelas X MIA 9) berjumlah 30 siswa diberi perlakuan dengan menggunakan model pembelajaran Learning Cycle 7E, sementara kelas kontrol (kelas $\mathrm{X}$ MIA 6) berjumlah 37 siswa diberi perlakuan dengan menggunakan metode pembelajaran Konvensional.

Waktu pelaksanaan ini pada bulan September-Oktober 2017. Dalam penelitian, teknik pengumpulan data diperoleh melalui tes (pretestpostest). Data yang digunakan adalah data kuantitatif. Data kuantitatif dari kedua kelas ada pretest-postest untuk membandingkan perbedaan hasil belajar pada kedua kelas.

\section{HASIL}

Penelitian menggunakan kelas $\mathrm{X}$ MIA SMA Negeri 10 Palembang. Kelas $\mathrm{X}$ MIA 9 adalah kelas eksperimen yang menggunakan model pembelajaran Learning Cycle 7E, sementara kelas X MIA 6 dengan menggunakan metode pembelajaran Konvensional. Data yang diperoleh dari hasil penelitian, dapat dilihat secara rinci berikut ini:

\section{A. Deskripsi Data Hasil Belajar Pada Ranah Kognitif}

Setelah melakukan penelitian, peneliti menganalisis data hasil belajar pada ranah kognitif menggunakan uji-t data berpasangan (Paired Sample $T$ test) dan uji-t data tidak berpasangan (Independent Sample T test). Adapun analisis data hasil belajar yang telah dilakukan adalah sebagai berikut:

\section{Deskripsi uji-t data berpasangan (paired sample $t$ test)}

Tabel 1. Hasil Uji Homogenitas dan Uji

\begin{tabular}{ccc}
\multicolumn{2}{c}{ Normalitas } & \\
\hline Kelas & $\begin{array}{c}\text { Uji } \\
\text { Homogenitas }\end{array}$ & $\begin{array}{c}\text { Uji } \\
\text { Normalitas }\end{array}$ \\
\hline Eksperi-men & 0,509 & 0,859 \\
\hline Kontrol & 0,041 & 0,856 \\
\hline
\end{tabular}

Tabel 2. Hasil Uji Data Berpasangan

\begin{tabular}{|c|c|c|c|c|c|c|c|c|c|}
\hline & & \multicolumn{5}{|c|}{ Perbe daan Data Berpasangan } & \multirow{3}{*}{$\mathbf{t}$} & & Sig. \\
\hline & & \multirow[t]{2}{*}{$\begin{array}{l}\text { Nilai } \\
\text { Tengah }\end{array}$} & \multirow[t]{2}{*}{$\begin{array}{l}\text { Std. } \\
\text { De viasi }\end{array}$} & \multirow[t]{2}{*}{$\begin{array}{l}\text { Std. } \\
\text { Kesalahan }\end{array}$} & \multicolumn{2}{|c|}{$\begin{array}{l}\text { Tingkat } \\
\text { keyape rcayaan } 95 \%\end{array}$} & & & \\
\hline & & & & & Bawah & Atas & & & \\
\hline Ekspermen & $\begin{array}{l}\text { Tes_awa } \\
\text { l-Tes } \\
\text { Akhir }\end{array}$ & 29,43700 & 8,34095 & 1,52284 & $\begin{array}{l}26,3224 \\
4\end{array}$ & 32,55156 & $\begin{array}{l}19,3 \\
30\end{array}$ & 29 & 0,000 \\
\hline Kontrol & $\begin{array}{l}\text { Tes_awa } \\
\text { l-Tes } \\
\text { Akhir }\end{array}$ & 25,21243 & 8,31136 & 1,36638 & $\begin{array}{l}22,4412 \\
9\end{array}$ & 27,98358 & $\begin{array}{l}18,4 \\
52\end{array}$ & 36 & 0,000 \\
\hline
\end{tabular}


2. Deskripsi uji-t data tidak berpasangan sample t test)

Uji-t data tidak berpasangan (independent sample $t$ test) bertujuan untuk mengetahui perbedaan hasil akhir belajar siswa pada kelas eksperimen dan kelas kontrol. Analisis data yang telah dilakukan dapat dilihat pada Tabel 3 dan Tabel 4.

Tabel 3. Hasil Uji Homogenitas dan Uji

\begin{tabular}{lcc}
\multicolumn{2}{c}{ Normalitas } & \\
\hline Kelas & $\begin{array}{l}\text { Uji } \\
\text { Homogenitas }\end{array}$ & $\begin{array}{l}\text { Uji } \\
\text { Normalitas }\end{array}$ \\
\hline $\begin{array}{l}\text { Eksperimen } \\
\text { dan Kontrol }\end{array}$ & 0,193 & 0,292 \\
\hline
\end{tabular}

Tabel 4. Hasil Uji-t Data Tidak Berpasangan Di Kelas Eksperimen dan Kelas Kontrol

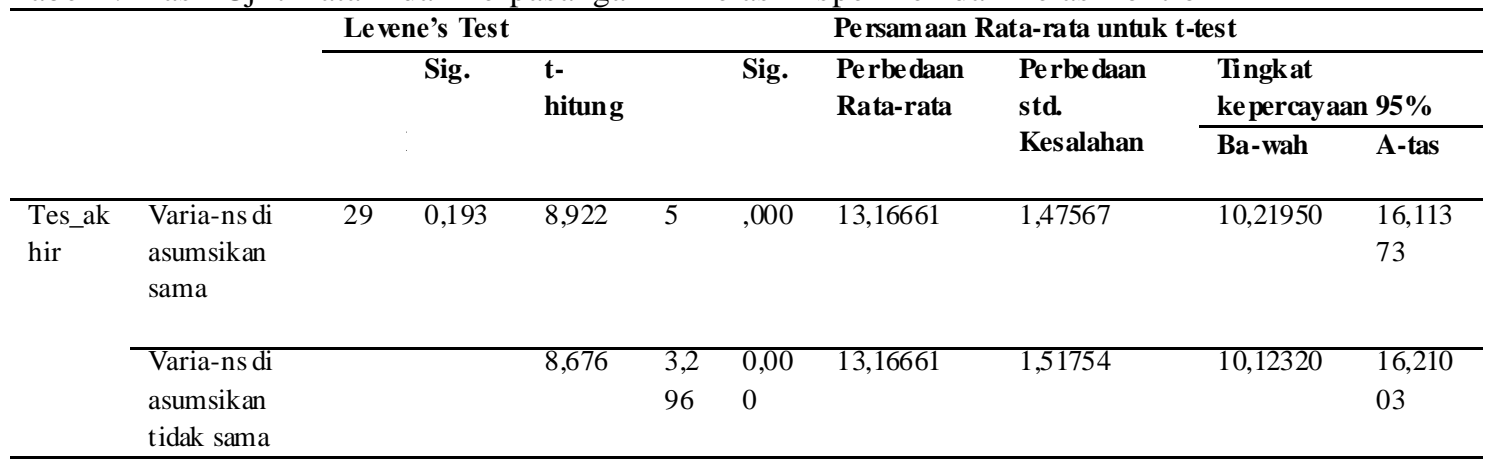

\section{B. Deskripsi Data Hasil Belajar} Pada Ranah Afektif (Sikap)

Tabel 5. Hasil Penilaian Ranah Afektif Pada Aspek Bekerjas ama

\begin{tabular}{|c|c|c|c|}
\hline \multirow[b]{2}{*}{ Nilai } & \multicolumn{2}{|c|}{ Jumlah Siswa } & \multirow{2}{*}{$\begin{array}{l}\text { Keteran- } \\
\text { gan }\end{array}$} \\
\hline & $\begin{array}{l}\text { Kelas } \\
\text { Eksper- } \\
\text { imen }\end{array}$ & $\begin{array}{l}\text { Kelas } \\
\text { Kontr-ol }\end{array}$ & \\
\hline $90-100$ & 20 & 13 & $\begin{array}{l}\text { Sangat } \\
\text { baik }\end{array}$ \\
\hline $81-90$ & 10 & 20 & Baik \\
\hline $71-80$ & 0 & 4 & Cukup \\
\hline $61-70$ & 0 & 0 & Kurang \\
\hline$\leq 60$ & 0 & 0 & $\begin{array}{l}\text { Sangat } \\
\text { kurang }\end{array}$ \\
\hline Jumlah & 30 & 37 & \\
\hline
\end{tabular}

Tabel 6. Hasil Penilaian Ranah Afektif Pada Aspek Bertanggung Jawab

\begin{tabular}{|c|c|c|c|}
\hline \multirow[b]{2}{*}{ Nilai } & \multicolumn{2}{|c|}{ Jumlah Siswa } & \multirow{2}{*}{$\begin{array}{l}\text { Keteran- } \\
\text { gan }\end{array}$} \\
\hline & $\begin{array}{l}\text { Kelas } \\
\text { eksperi - } \\
\text { men }\end{array}$ & $\begin{array}{c}\text { Kelas } \\
\text { kontr- } \\
\text { ol }\end{array}$ & \\
\hline $90-100$ & 14 & 10 & Sangat baik \\
\hline $81-90$ & 15 & 22 & Baik \\
\hline $71-80$ & 1 & 5 & Cukup \\
\hline $61-70$ & 0 & 0 & Kurang \\
\hline$\leq 60$ & 0 & 0 & $\begin{array}{l}\text { Sangat } \\
\text { kurang }\end{array}$ \\
\hline Jumlah & 30 & 37 & \\
\hline
\end{tabular}

C. Deskripsi Data Hasil Belaja r Pada Ranah Psikomotorik

Tabel 7. Hasil Penilaian Ranah Psiko motorik

\begin{tabular}{lccc}
\hline Nilai & \multicolumn{2}{c}{ Jumlah Siswa } & Keteran-gan \\
& $\begin{array}{l}\text { Kelas } \\
\text { eksperi- } \\
\text { men }\end{array}$ & $\begin{array}{l}\text { Kelas } \\
\text { kon tr- } \\
\text { ol }\end{array}$ & \\
\hline $85-100$ & 29 & 3 & Sangat baik \\
$70-84$ & 1 & 34 & Baik \\
$55-69$ & 0 & 0 & Cukup \\
$40-50$ & 0 & 0 & Kurang \\
$\leq 39$ & 0 & 0 & $\begin{array}{c}\text { Sangat } \\
\text { kurang }\end{array}$ \\
\hline Jumlah & $\mathbf{3 0}$ & $\mathbf{3 7}$ & \\
\hline
\end{tabular}

\section{PEMBAHASAN}

\section{A. Hasil Belajar Pada Ranah Kognitif}

1. Hasil Belajar Pada Kelas Eksperimen Menggunakan Model Pembelajaran Learning Cycle 7E

Proses belajar mengajar dilakukan di kelas X MIA 9 sebagai kelas eksperimen dengan menerapkan model pembelajaran Learning Cycle 7E. Pada penelitian menggunakan 
Learning Cycle 7E ini, dalam satu kelas terdiri dari 30 siswa dibagi menjadi 6 kelompok. Masing-masing kelompok, terdiri dari 5 orang dan tiap anggota memiliki peran yang berbeda-beda yaitu ; satu siswa sebagai moderator, satu siswa sebagai notulen, dan dua siswa sebagai pembaca materi. Pembagian anggota kelompok berdasarkan absen kehadiran siswa, sehingga dalam satu kelompok siswa mempunyai kemampuan yang hampir sama, agar penyebaran siswa merata dan seimbang.

Tabel 2 menunjukkan bahwa nilai signifikasi pada kelas X MIA 9 (eksperimen) sebesar 0,000. Dari pernyataan tersebut, maka dapat dinyatakan bahwa Ha diterima dan $\mathrm{H} 0$ ditolak. Hal ini menunjukkan bahwa model pembelajaran Learning Cycle 7E dengan bantuan media Power Point dan LKS pada materi keanekaragaman hayati kelas X MIA di SMA Negeri 10 Palembang berpengaruh terhadap hasil belajar siswa. Berdasarkan hasil Tabel 4.16 yang telah dijelaskan, maka dapat dibuat dalam bentuk diagram batang perbandingan antara hasil belajar ranah kognitif (pengetahuan) pada tes awal (pretest) dengan tes akhir (postest) yang telah dilakukan. Diagram batang tersebut, telah disajikan pada Gambar 1 berikut ini:

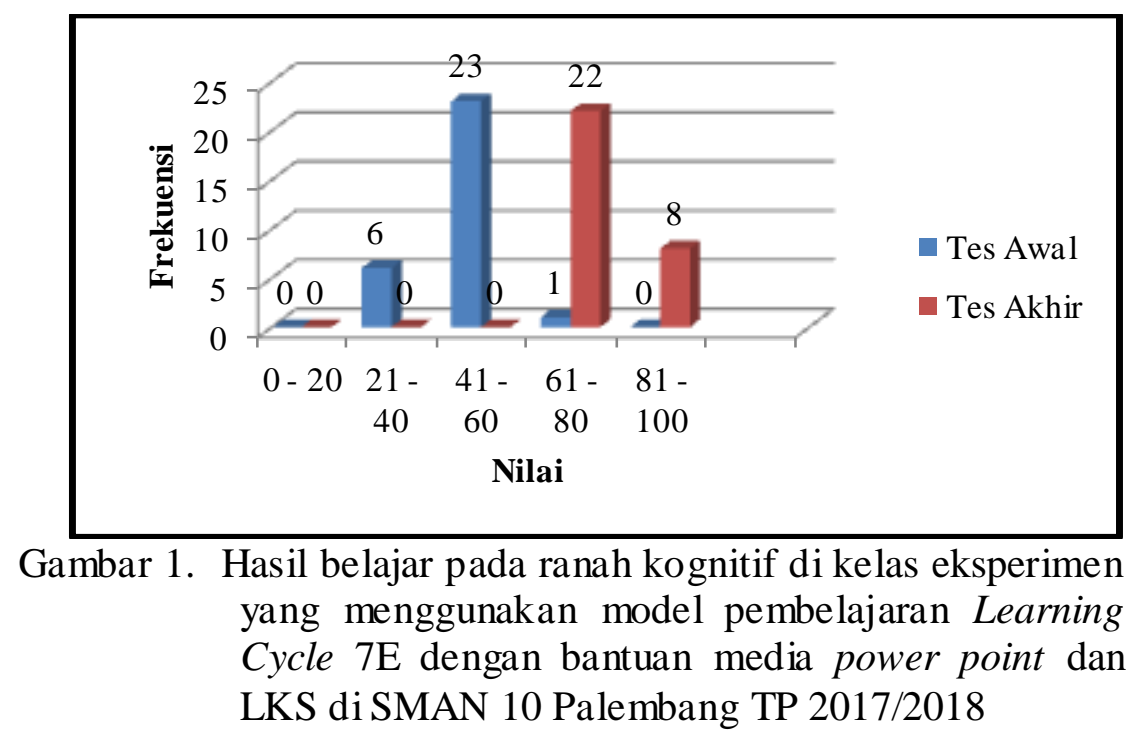

Gambar 1 menunjukkan bahwa ada pengaruh model pembelajaran Learning Cycle 7E. Untuk melihat persentase besarnya pemberian model pembelajaran Learning Cycle 7E, maka dilanjutkan dengan menghitung menggunakan rumus omega dan effect size $d$ dependent t-test. Hasil yang didapat dari analisis menggunakan rumus effect size $d$ adalah 4,63 yang menyatakan bahwa adanya perbedaan antara nilai tes awal (pretest) dengan nilai tes akhir (postest). Sedangkan hasil perhitungan dengan menggunakan rumus omega adalah 0,86 yang menyatakan bahwa adanya pengaruh pemberian model pembelajaran Learning Cycle 7E pada kelas eksperimen dengan persentase $86 \%$. Hal ini juga sejalan dengan pernyataan Muswahida, Subiki, dan Supriadi (2015), yang menyatakan bahwa ada pengaruh penggunaan model pembelajaran Learning Cycle $7 \mathrm{E}$ secara signifikan terhadap hasil 
belajar siswa pada ranah kognitif (pengetahuan).

\section{Hasil Belajar Pada Kelas Kontrol yang Menggunakan Metode Konvensional}

Proses kegiatan belajar mengajar juga dilakukan di kelas $X$ MIA 6 sebagai kelas kontrol dengan menggunakan metode pembelajaran konvensional. Pada kelas kontrol, dalam satu kelas terdiri dari 37 siswa dibagi menjadi 6 kelompok. Masingmasing kelompok terdiri dari 6 atau 7 orang dan tiap anggota memiliki peran yang berbeda-beda, yaitu; satu siswa sebagai moderator, satu siswa sebagai notulen dan tiga siswa sebagai pemateri. Pembagian anggota kelompok berdasarkan absen kehadiran siswa, sehingga dalam satu kelompok mempunyai kemampuan yang hampir sama, agar penyebaran siswa merata dan seimbang.

Tabel 2. menunjukkan bahwa nilai signifikasi pada kelas kontrol berdasarkan uji-t data berpasangan (paired sample $t$ test) sebesar 0,000. Dari pernyataan tersebut, dapat dinyatakan bahwa Ha diterima dan $\mathrm{H} 0$ ditolak artinya bahwa metode konvesionalyang telah digunakan pada kelas X MIA 6 berpengaruh terhadap hasil belajar siswa dengan bantuan media power point pada materi keanekaragaman hayati kelas X MIA 6 di SMA Negeri 10 Palembang. Hasil tes awal (pretest) dan tes akhir (postest) di kelas X MIA 6 (kontrol), disajikan dalam bentuk diagram batang. Diagram batang tes awal (pretest) dan tes akhir (postest), dapat dilihat pada Gambar 2 berikut ini:

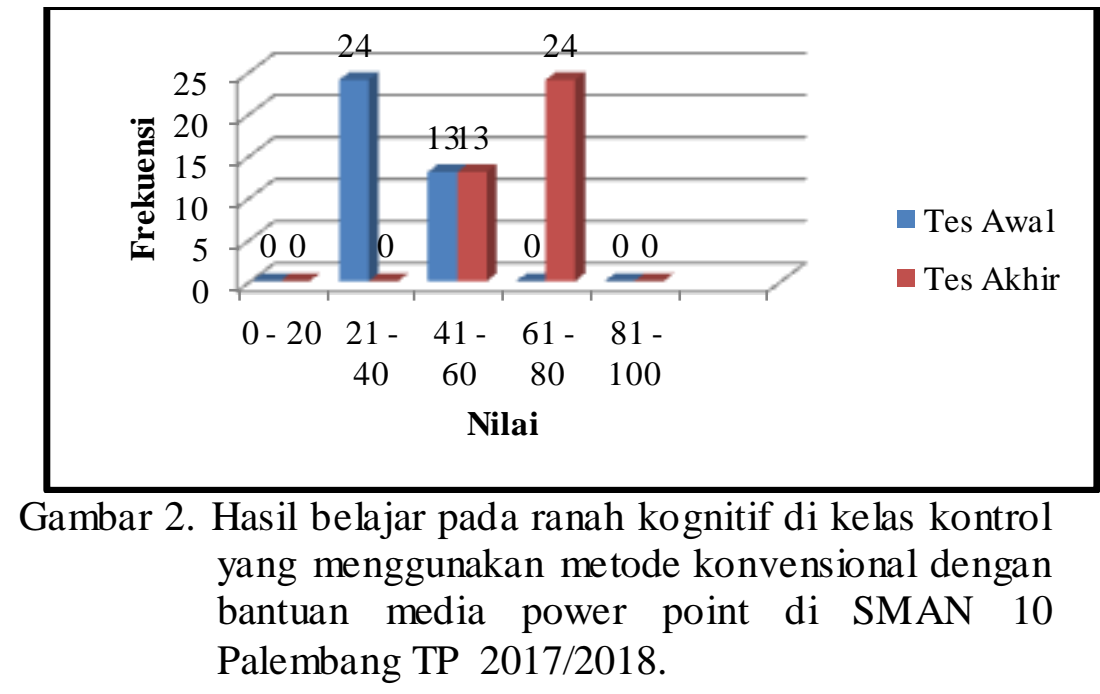

Gambar 2 menunjukkan bahwa, ada pengaruh penggunaan metode konvensional di kelas kontrol. Untuk memperoleh persentase besarnya pemberian perlakuan dengan menggunakan metode konvensional maka dilanjutkan dengan perhitungan omega dan effect size d. Hasil yang didapat dari analisis dengan menggunakan effect size $d$ adalah
135,60 yang berarti bahwa adanya perbedaan antara nilai tes awal (pretest) dengan nilai tes akhir (postest) di kelas kontrol. Sedangkan hasil perhitungan dengan menggunakan rumus omega adalah 0,82 yang menyatakan adanya pengaruh pemberian metode konvensional pada kelas kontrol dengan persentase $82 \%$. 
Hasil akhir belajar ranah kognitif yang telah dilakukan di kelas eksperimen dengan menggunakan model pembelajaran Learning Cycle $7 \mathrm{E}$ dan kelas kontrol dengan menggunakan metode konvensional menunjukkan bahwa ada perbedaan antara hasil akhir belajar di kelas eksperimen dan kelas kontrol. Hasil akhir belajar pada ranah kognitif di kelas eksperimen dan di kelas kontrol, disajikan dalam bentuk diagram batang. Diagram batang tersebut, dapat dilihat pada Gambar 3 berikut ini:

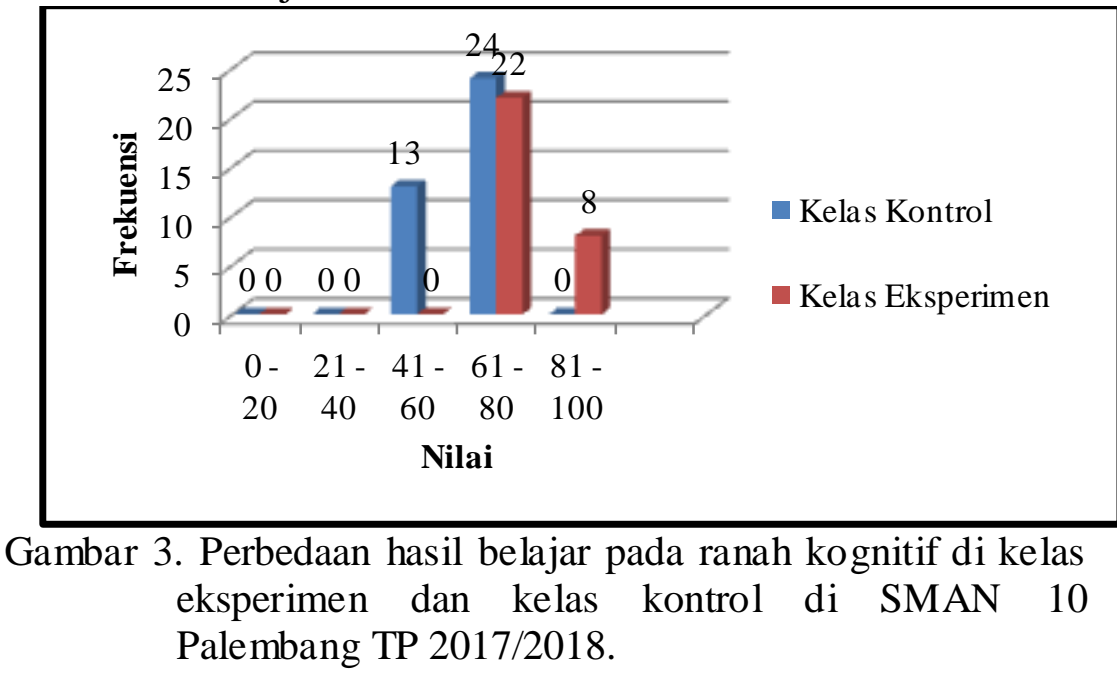

Gambar 3 menunjukkan bahwa, ada perbedaan antara hasil akhir belajar di kelas eksperimen dan di kelas kontrol. Untuk melihat persentase besarnya perbedaan hasil akhir belajar di kelas eksperimen dan kelas kontrol ini akan di lanjutkan dengan menggunakan rumus effect size $r$ independent t-test. Hasil yang didapat dari analisis menggunakan rumus effect size $r$ independent t-test adalah 0,74 yang menyatakan bahwa ada perbedaan hasil akhir belajar antara kelas eksperimen dan kelas kontrol dengan persentase $74 \%$. Hal ini juga sejalan dengan penelitian yang telah dilakukan oleh Yani, Enawaty dan Lestari (2015), yang menyatakan bahwa ada perbedaan hasil belajar pada kelas eksperimen yang menggunakan model pembelajaran Learning Cycle 7E dengan kelas kontrol menggunakan metode konvensional. Hal ini juga ditambahkan oleh pendapat Imaniyah,
Siswoyo, dan Bakri (2015), yang menyatakan bahwa hasil belajar di kelas eksperimen yang menggunakan model pembelajaran Learning Cycle 7E lebih tinggi dibandingkan dengan hasil belajar di kelas kontrol yang menggunakan metode konvensional. Hasil belajar pada kelas eksperimen dan kelas kontrol dalam penelitian ini juga sesuai dengan teori Sadia yang telah di jelaskan pada bab 2 sebelumnya. Menurut Sadia ( 2014), kelebihan dari model pembelajaran Learning Cycle 7E, antara lain: a) guru akan dapat memilih strategi pembelajaran yang lebih efektif, berdasarkan hasil pengungkapan pengetahuan awal siswa (elicit); b) siswa tergugah untuk mengingat kembali terhadap materi pelajaran yang telah mereka pelajari sebelumnya; c) melalui kegiatan engagement, siswa akan menjadi lebih aktif dan tergugah rasa ingin tahunya; d) melalui kegiatan eksplorasi siswa 
akan mengalami proses belajar penemuan, sehingga konsep-konsep yang dipelajari akan menjadi lebih bermakna dan tahan lama; e) kemampuan berpikir tingkat tinggi (berpikir kritis dan berpikir kreatif) siswa akan terakomodasi dalam proses pembelajaran; f) melalui kegiatan pada fase eksplanasi, siswa akan memiliki kemampuan komunikasi ilmiah yang lebih baik; g) melalui kegiatan pada fase pengembangan (extended), pemahaman dan penguasaan konsep siswa akan menjadi sangat kuat dan status pengetahuannya dapat mencapai status fruitfull.

disamping kelebihan, model pembelajaran Learning Cycle 7E juga memiliki keterbatasan atau kelemahan. menurut soebagio dalam ngalimun (2012), kelemahan model pembelajaran Learning Cycle 7E adalah sebagai berikut: a) efektivitas pembelajaran rendah jika seorang guru kurang menguasai materi dan langkahlangkah pembelajaran; b) menuntut kesungguhan dan kreativitas guru dalam merancang dan melaksanakan proses pembelajaran; c) memerlukan pengelolaan kelas yang lebih terencana dan terorganisasi; d) memerlukan waktu dan tenaga yang lebih banyak dalam menyusun rencana dan melaksanakan pembelajaran. Berdasarkan kelebihan dan kelemahan yang telah dijelaskan oleh Sadia dan Soebagio, maka dapat disimpulkan bahwa model pembelajaran Learning Cycle $7 E$ sangat berpengaruh pada hasil belajar siswa.

Berdasarkan hasil tes awal (pretest) dan tes akhir (postest), perbedaan hasil belajar pada ranah kognitif di kelas ekperimen dan kelas kontrol dalam penelitian ini juga dipengaruhi oleh beberapa faktor. Pada kelas eksperimen, faktor yang mempengaruhi hasil belajar siswa pada ranah kognitif, yaitu: karena mereka memiliki semangat dan minat belajar yang tinggi, walaupun pada saat proses kegiatan pembelajaran berlangsung ada beberapa siswa yang membuat kegaduhan di dalam kelas tetapi mereka masih tetap memperhatikan ketika guru menjelaskan materi sehingga hasil belajar yang diperoleh pada ranah kognitif mencapai nilai maksimal. Sedangkan di kelas kontrol, siswa mempunyai kurang bersemangat dan memiliki minat belajar yang rendah. Hal ini dapat dilihat pada saat proses kegiatan pembelajaran berlangsung, ada beberapa siswa yang sibuk mengobrol dengan teman sebangkunya, ada siswa yang tertidur ketika guru menjelaskan materi dan ada juga siswa yang memperhatikan ketika guru menjelaskan materi mulai dari jam pelajaran berlangsung hingga berakhirnya kegiatan belajar-mengajar sedang diajarkan. Sehingga hasil belajar yang mereka peroleh tidak maksimal. Faktor yang mempengaruhi hasil belajar ini juga telah diteliti oleh Syarifudd in (2011), yang menyatakan ada 2 faktor yang mempengaruhi hasil belajar, yaitu: a) Faktor internal, antara lain: kondisi jasmani dan rohani siswa, kematangan/pertumbuhan, kecerdasan, minat, latihan dan kebiasaan belajar, serta motivasi pribadi dan konsep diri; b) faktor eksternal, antara lain: pendekatan belajar, kondisi keluarga, guru dan cara mengajarnya, serta kesempatan yang tersedia dan motivasi sosial. Salah satu dari faktor tersebut ialah kecerdasan dan minat belajar. Jika seorangan siswa memiliki kecerdasan yang kurang dan minat belajar juga rendah, maka hal tersebut akan berpengaruh pada hasil belajar yang mereka peroleh. 
B. Hasil Belajar Pada Ranah Afektif (Sikap)

1. Hasil Belajar Ranah Afektif Pada Aspek Bekerja Sama

Hasil penelitian ranah afektif di kelas eksperimen dan di kelas kontrol pada aspek berkerjasama menunjukkan bahwa, nilai afektif di kelas eksperimen terdapat $66 \%$ siswa yang termasuk dalam kategori "Sangat Baik" dan 33\% siswa yang termasuk dalam kategori "Baik". Sedangkan di kelas kontrol menunjukkan bahwa, ada $35 \%$ siswa yang termasuk dalam kategori "Sangat Baik", 54\% siswa yang termasuk dalam kategori "Baik" dan $10 \%$ siswa yang termasuk dalam kategori "Cukup Baik". Hasil belajar ranah afektif (sikap) pada aspek bekerjasama di kelas ekperimen dan kelas kontrol disajikan dalam bentuk diagram batang, dapat dilihat pada Gambar 4 berikut ini:

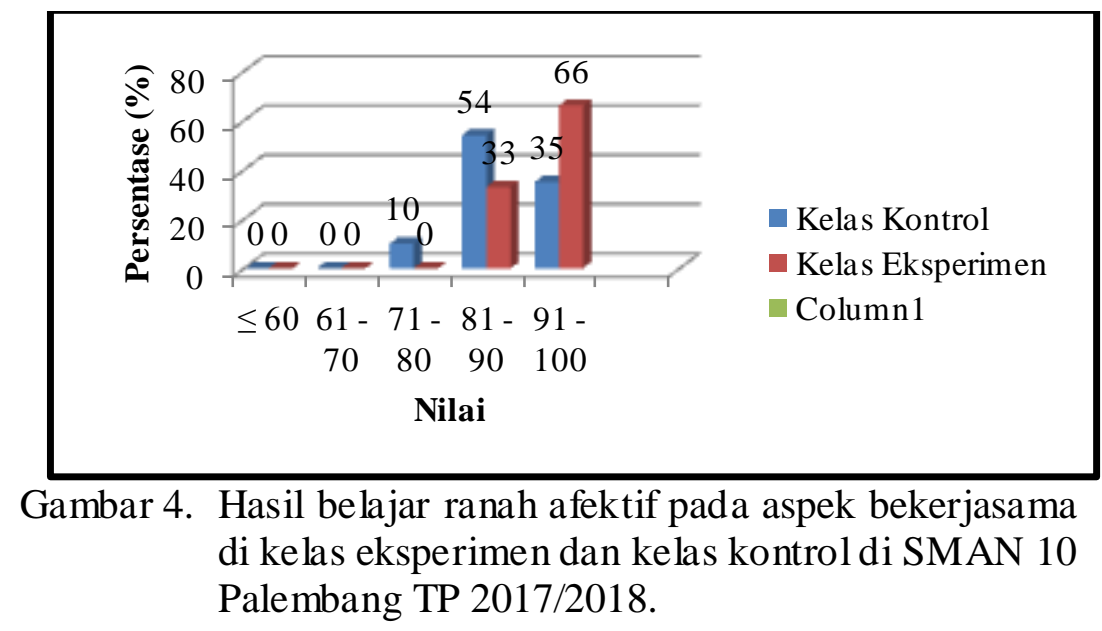

Gambar 4 menunjukkan bahwa, hasil belajar ranah afektif pada aspek bekerjasama di kelas eksperimen lebih tinggi dibandingkan di kelas kontrol. Perbedaan hasil belajar ranah afektif pada aspek bekerjasama, disebabkan oleh beberapa faktor. Faktor yang menyebabkan perbedaan hasil belajar pada ranah afektif (sikap) di kelas ekperimen dan di kelas kontrol yang dilihat berdasarkan dari hasil lembar observasi, yaitu : a) Pada kelas eksperimen, siswa memperhatikan ketika guru dan temannya menjelaskan materi yang sedang dipelajari, berpartisipasi dalam mempresentasikan hasil diskusi, Mengajukan usul, aktif berpendapat atau memberikan arahan tentang tugas yang harus diselesaikan dan memiliki kerjasama yang baik dalam mengerjakan tugas yang diberikan sehingga hasil belajar pada ranah afektif mencapai nilai yang maksimal; b) Pada kelas kontrol, siswa kurang memperhatikan ketika guru dan temannya menjelaskan materi yang sedang dipelajari, kurang berpartisipasi dalam mempresentasikan hasil diskusi, Mengajukan usul, aktif dan tidak memiliki kerjasama yang baik dalam mengerjakan tugas yang diberikan sehingga hasil belajar pada ranah afektif tidak mencapai maksimal.

\section{Hasil Belajar Ranah Afektif Pada Aspek Bertanggung Jawab}

Hasil penelitian ranah afektif (sikap) pada aspek bertanggung jawab 
menunjukkan bahwa, di kelas eksperimen terdapat $46 \%$ siswa yang termasuk kategori "Sangat Baik", $50 \%$ siswa yang termasuk dalam kategori "Baik" dan 3\% siswa yang termasuk dalam kategori "Cukup Baik". Sedangkan di kelas kontrol menunjukkan bahwa terdapat $27 \%$ siswa yang termasuk dalam kategori
"Sangat Baik", 59\% siswa yang termasuk dalam kategori "Baik" dan $13 \%$ yang termasuk dalam kategori "Cukup Baik". Hasil belajar ranah afektif pada aspek bertanggung jawab di kelas ekperimen dan kelas kontrol, juga disajikan dalam bentuk diagram batang yang dapat dilihat pada Gambar 5 berikut ini:

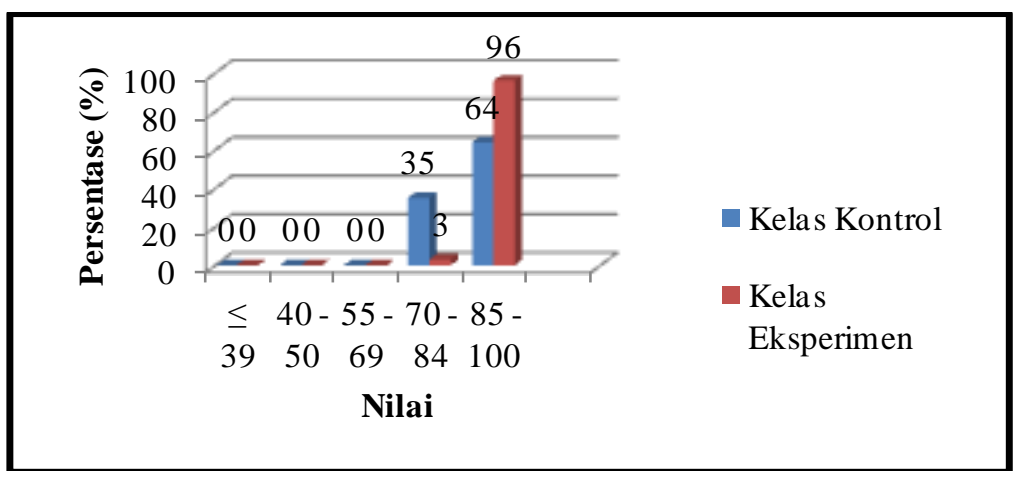

Gambar 5. Hasil belajar ranah afektif pada aspek bertanggung jawab di kelas eksperimen dan kelas kontrol di SMAN 10 Palembang TP $2017 / 2018$.

Gambar 5 menunjukkan bahwa hasil belajar ranah afektif pada aspek bertanggung jawab di kelas eksperimen lebih tinggi dibandingkan di kelas kontrol. Hal tersebut karena dipengaruhi oleh dari oleh beberapa faktor sehingga berpengaruh pada hasil belajara siswa. Faktor yang menyebabkan perbedaan hasil belajar ranah afektif pada aspek bertangggung jawab di kelas ekperimen dan di kelas kontrol yang dilihat berdasarkan dari hasil lembar observasi, menunjukkan bahwa : a) di kelas eksperimen, siswa mempunyai motivasi dan minat belajar yang tinggi, menyelesaikan tugas yang telah diberikan guru secara tepat waktu dan memperhatikan ketika guru menjelaskan materi yang diajarkan sehingga hasil belajar pada ranah afektif (sikap) mencapai nilai maksimal; b) di kelas kontrol, siswa mempunyai motivasi dan minat belajar yang kurang dalam mengikuti kegiatan pembelajaran, tidak memperhatikan ketika guru menjelaskan materi pelajaran dan tidak menyelesaikan tugas tepat waktu sehingga hasil belajar pada ranah afektif yang diperoleh tidak mencapai maksimal. Hal ini juga sejalan dengan penelitian yang telah dilakukan oleh Aritonang (2008), yang menyatakan bahwa salah satu penyebab hasil belajar rendah adalah minat belajar dan motivasi belajar. Karena hal tersebut sangat berpengaruh pada hasil belajar siswa.

Berdasarkan hasil belajar ranah afektif di kelas eksperimen dan kelas kontrol yang meliputi : aspek bekerja sama dan aspek bertanggung jawab, maka dapat disimpulkan bahwa hasil belajar ranah afektif di kelas eksperimen dengan menggunakan model pembelajaran Learning Cycle 7E lebih tinggi dibandingkan dengan kelas kontrol yang menggunakan metode 
konvensional. Hal ini juga sejalan dengan penelitian yang telah dilakukan oleh Apriani, Saptorini dan Nurhayati (2012), yang menyatakan bahwa adanya perbedaan hasil belajar pada ranah afektif (sikap) di kelas eksperimen yang menggunakan model pembelajaran Learning Cycle $7 \mathrm{E}$ dengan kelas kontrol yang menggunakan metode konvensional. Model pembelajaran Learning Cycle 7E ini juga dibuktikan dalam penelitian Septian pada tahun 2011. Hasil penelitian Septian (2011), menunjukkan bahwa model pembelajaran Learning Cycle $7 \mathrm{E}$ lebih berpengaruh terhadap hasil belajar ranah afektif dibandingkan dengan kelas kontrol yang menggunakan metode konvensional. Hal ini juga di perkuat dari penelitian Aziz (2013), yang menjelaskan bahwa salah satu kelebihan model pembelajaran Learning Cycle $7 \mathrm{E}$ adalah memberikan motivasi kepada siswa untuk menjadi lebih aktif dan menambah rasa keingintahuan siswa dan memberikan kesempatan kepada siswa untuk berpikir, mencari, menemukan, dan menjelaskan contoh penerapan konsep yang telah dipelajari. Berdasarkan kelebihan tersebut, maka dapat disimpulkan bahwa model pembelajaran Learning Cycle 7E berpengaruh terhadap hasil belajar pada ranah afektif.

\section{Hasil Belajar Pada Ranah Psikomotorik (Keterampilan)}

Hasil penelitian pada ranah psikomotorik menunjukkan bahwa, hasil penilaian ranah psikomotorik di kelas eksperimen terdapat $96 \%$ siswa yang termasuk dalam kategori "Sangat Baik" dan 3\% siswa yang termasuk dalam kategori "Baik". Sedangkan di kelas kontrol menunjukkan bahwa, terdapat $8 \%$ siswa yang termasuk dalam kategori "Sangat Baik" dan 91\% siswa yang termasuk dalam kategori "Baik". Hasil belajar pada ranah psikomotorik di kelas ekperimen dan kelas kontrol juga disajikan dalam bentuk diagram batang, yang dapat dilihat pada Gambar 6 berikut ini:

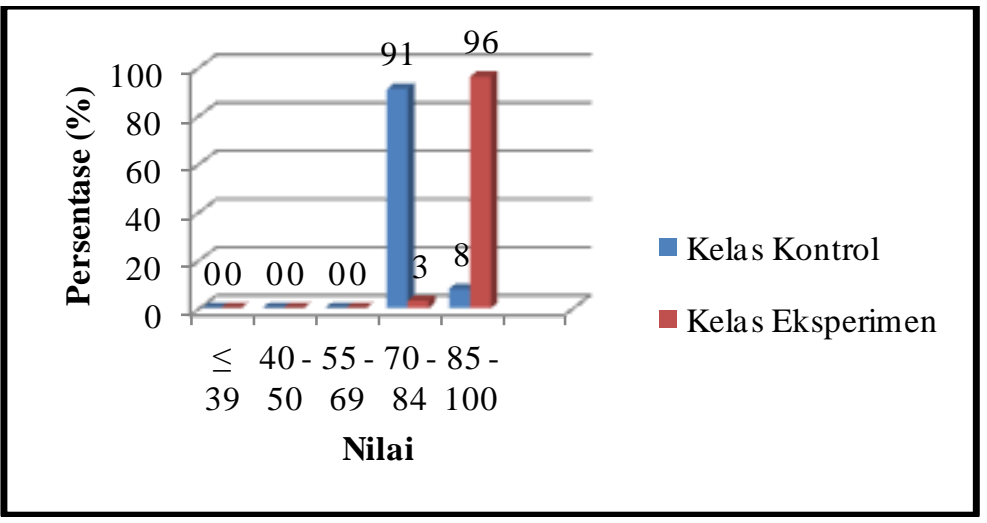

Gambar 6. Hasil belajar ranah psikomotorik di kelas eksperimen dan kelas kontrol di SMAN 10 Palembang TP 2017/2018. 
Gambar 6 menunjukkan bahwa hasil belajar pada ranah psikomotorik di kelas eksperimen lebih tinggi dibandingkan di kelas kontrol. Hal ini juga sejalan dengan penelitian yang telah dilakukan oleh Qulud, Wahidin dan Mayurningsih (2015), yang menyatakan bahwa adanya perbedaan hasil belajar pada ranah psikomotorik (keterampilan) di kelas eksperimen yang menggunakan model pembelajaran Learning Cycle 7E dengan kelas kontrol yang menggunakan metode konvensional.

Salah satu faktor yang mempengaruhi hasil belajar pada ranah psikomotorik di kelas ekperimen dan kelas kontrol yang dilihat berdasarkan dari hasil laporan diskusi, yaitu : a) di kelas eksperimen, siswa mempunyai semangat yang tinggi walaupun dalam kegiatan pembelajaran ada beberapa siswa yang membuat kegaduhan di kelas dan memperhatikan ketika guru menjelaskan cara dalam pembuatan laporan hasil diskusi sehingga hasil belajar pada ranah psikomotorik yang diperoleh mencapai nilai maksimal; b) di kelas kontrol, antara lain : siswa mempunyai kurang bersemangat dalam mengikuti kegiatan pembelajaran dan kurang memperhatikan ketika guru menjelaskan cara membuat laporan hasil diskusi sehingga hasil belajar pada ranah psikomotorik yang diperoleh tidak mencapai maksimal. Faktor yang mempengaruhi hasil belajar pada ranah psikomotorik ini telah dibuktikan oleh Sutrisno (2012), yang menyatakan bahwa salah faktor yang mempengaruhi hasil belajar adalah faktor psikologi. Salah satu contoh faktor psikologi, yaitu; siswa tersebut sedang sakit atau sada masalah di rumah, sehingga akan berpengaruh pada semangat belajar siswa dan kurang memperhatikan ketika guru menjelaskan materi. Maka hal tersebut akan berpengaruh pada hasil belajar siswa.

\section{KESIMPULAN}

1. Ada pengaruh secara signifikan penerapan model pembelajaran Learning Cycle 7E terhadap hasil belajar siswa dengan bantuan media power point dan LKS pada materi keanekaragaman hayati kelas X MIA di SMA Negeri 10 Palembang tahun ajaran 2017/2018.

2. Adanya perbedaan secara signifikan antara hasil akhir belajar menggunakan model pembelajaran Learning Cycle 7E dan pembelajaran konvensional.

\section{DAFTAR RUJUKAN}

Apriani, D. N., Saptorini dan S, Nurhayati. 2012. Pembelajaran Learning Cycle 7E Terhadap Hasil Belajar dan Keterampilan Generik Sains Siswa. (Online).https://journal.unnes.ac. id/sju/index.php/chemined/article view/728/960.

Aritonang, K. T. 2008. Minat dan Motivasi dalam Meningkatkan Hasil Belajar Siswa. Jurnal Pendidikan Penabur. No.10/Tahun ke-7/Juni 2008. (Online).

http://www.academia.edu/971729 O/Minat_dan_Motivasidalam_M eningkatkan_Hasil_Belajar_Sisw a.

Ngalimun. 2016. Strategi dan Model Pembelajaran. Yogyakarta: Aswaja Pressindo.

Qulud, W., dan Y. Mayurningsih, 2015. Penerapan Model Pembelajaran Learning Cycle 7E Untuk Meningkatkan Literasi Sains Siswa Pada Konsep Sistem 
Reproduksi Kelas XI di SMA

Negeri 1 Arjawinangun.

(Online).

http://www.syekhnurjati.ac.id/jur nal/index.php/sceducatia/article/ view/268/415.

Sadia, I. W. 2014. Model-Model Pembelajaran Sains

Konstruktivistik. Jogjakarta: Graha Ilmu.

Septian, D. 2011. Pengaruh Model Learning Cycle $7 E$ dalam Pembelajaran Fisika Terhadap Hasil Belajar Fisika Siswa Man Rembang Tahun Ajaran 2010/2011. (Online). http://digilib.uinsuka.ac.id/5954/1/bab\%20i\%2cv $\% 2 c \% 20$ daftar\%20pustaka.pdf.

Sutrisno, W. 2012. Implementasi Model Learning Cycle $7 E$ Terhadap Motivasi Belajar Siswa Serta Terkait Hasil Belajar Biologi. (Online). http://www.jurnal.fkip.uns.ac.id/i ndex.php/prosbio/article/downlo ad/1041/694.

Syarifuddin, A. 2011. Penerapan Model Pembelajaran Cooperative Belajar dan FaktorFaktor yang Mempengaruhinya. Vol. XVI, No. 01. (Online). http://jurnal.radenfatah.ac.id/ind ex.php/tadib/articledownload/57/ 52.

Yani, N. D., E, Enawaty, dan I, Lestari. 2015. Pengaruh Pembelajaran Learning Cycle $7 E$ Terhadap Motivasi Belajar dan Hasil Belajar Pada Materi Koloid. (Online). http://jurnal.untan.ac.id/index.ph p/jpdpb/article/view/12586. 